\title{
IUGS Commission on Geoscience Education, Training and Technology Transfer (COGE)
}

\section{Report: Commission Meeting 21 September 2006 Held at GeoSciEd V Conference, Bayreuth, Germany}

\author{
Attendees \\ Gary Lewis (Chair), Geological Society of America - USA \\ Chris King, Earth Science Education Unit, Keele University - UK \\ Chang-Jong Kim, Dept of Earth Science Education, Seoul National Univ - Korea \\ Alan Morgan, Waterloo University - Canada \\ Ian Clark, University of South Australia, President of IGEO - Australia
}

The Commission met for two hours to discuss
a. International Year of Planet Earth activities
b. International Earth science education survey
c. Website development
d. Training and technology transfer issues
e. New Commissioners
f. Budget

A. International Year of Planet Earth

The Commission discussed its options for supporting groups who were looking to undertake activities for IYPE. It decided that it would undertake two specific tasks.

a. The Commission would support the International Earth Science Olympiad (IESO) by providing the ISEO organising committee (Korea) a letter of support from the Commission if requested to assist them to obtain additional funding and support from IUGS/IYPE.

b. The Commission will support the Earth Science Education Unit (ESEU) (United Kingdom) to undertake the IYPE Teacher Education Project

The project will:

- Develop two-day courses for the professional development of teachers of Earth science in four developing countries:
$\circ$ Indonesia
○ The Philippines
○ South Africa
- Trinidad

- Prepare written and other accurate, attractive and interactive countryspecific materials to support these courses

- Present the two day courses to around 500 teachers in each country (who at normal ratios, will influence more than 150,000 children) 
- Develop a sustainable network to encourage the rollout of the initiative in each of the four countries

- Research the initiatives with a vision to implement similar strategies in other developing countries in the future

- Will be based on the successful Earth Science Education Unit initiative for the professional development of teachers of Earth science, piloted in England and Wales and subsequently transferred to a country with a different educational system, Scotland.

- Involve a carefully planned three-year development and rollout programme

\section{B. International Earth Science Education Survey}

The Commission worked with the International Geoscience Education Organisation (IGEO) to undertake a survey of the status of Earth science education in schools internationally. Twenty countries responded and the data is being collated. The preliminary survey results were discussed, and the project leader, Dr Ian Clark (Australia), will incorporate the final country data (India, USA) and prepare the research for publication. IGEO will look to publish the results in IUGS Episodes. The final report is due to the Commission by the end of 2006.

\section{Website Development}

The Commission was very pleased with the initial development of the COGE website by Greg McNamara (Australia). The call has been put out for Commissioners to feed Mr McNamara with designated links and information to continue to keep the site updated.

\section{Training and Technology Transfer Issues}

The Commission considered a number of options to increase its work in training and technology transfer into developing countries. It will continue to seek and invite people with expertise in this area to join the Commission. One program discussed at length was the development of teachers in developing countries identified in the IGEO survey. Dr King's ESEU program, which the Commission would support for the IYPE, is looking to diversify into the training of teachers and the transfer of Earth systems science concepts into schools in developing counties identified by the IGEO survey. Countries identified include: South Africa, Philippines, Trinidad and Indonesia.

The Commission will also post international training and technology transfer opportunities, like short courses and technical training, on it's website

\section{E. New Commissioners}

We are looking to find people to be active on the Commission and the following people have been identified and will be approached by the Commission in the next month:

- Dr. Sylke Hlawatsch, IPN Leibniz-Institut of Science Education, Germany

- Dr Ian MacKay, University of the Witwatersrand, South Africa

- Dr Sandra Barr, Acadia University, Wolfville, Nova Scotia, Canada 
F. Budget

For the 2006 FY, the Commission has expended the following from it's budget:

Commission budget for 2006: $\$ 4,000$ US

$\$ 2,000$ Initial development and maintenance of the IUGS COGE website $\$ 2,000$ To support the International Earth Science Education Survey

The Commission will seek $\$ 5,000$ US from IUGS to operate its programs during the 2007 FY. These funds will be used to:

\$2,000 Maintenance and continued development of the website for IYPE $\$ 2,000$ Seed funding for ESEU teacher development program

$\$ 1,000$ Conference phone calls, postage and materials

Gary Lewis

COGE Chair

13 December 2006 


\section{IUGS Commission on Geoscience Education, Training and Technology Transfer (COGE)}

\section{Commission Action Plan 2005-2009}

\section{Commission Members:}

Gary Lewis (Chair), Geological Society of America - USA

Wesley Hill (Secretary/Treasurer), Geological Society of America - USA

Chris King, Earth Science Education Unit, Keele University - UK

Greg McNamara, Geological Society of Australia - Australia

Chan-Jong Kim, Earth Science Education, Seoul National University - Korea

Alan Morgan, Waterloo University - Canada

Ian Clark, IGEO President, University of Adelaide - Australia

\section{Progress Report Dec 2006}

This action plan will be undertaken in association with member and other agencies including, but not limited to, those listed in the Terms of Reference for this Commission.

Over the life of this Commission, it will:

1. Develop a list of expert international contacts to provide input into Commission activities (In production)

2. Develop and operate a Commission web site and list-server or email list for the dissemination of materials to the wider community (Completed initial development and now ongoing)

3. Assist the International Geoscience Education Organization (IGEO) in undertaking a world wide survey of the Earth science perspective of school education and provide an avenue of dissemination of survey outcomes. From this survey, target developing and transitional countries in which the work of this Commission can have the greatest impact (Survey complete, data being compiled)

4. Identify those countries that have set the benchmark for the inclusion of Earth science in their curriculums and promote these benchmark examples to all countries at the appropriate level (Data from survey will be used to undertake this task)

5. Develop and release a series of benchmark strategy documents that can be used for countries to establish Earth science education and outreach programs. (Under development)

6. Develop and maintain contact with other agencies and local NGO's involved in Earth science education and outreach activities with the aim of greater dissemination of information to a wider audience (Continuing)

7. Assist IGEO in its efforts to develop and run the GeoSciEd conference which is held every four years and is the premier international geoscience education conference (Commission met at conference in Germany, Sept 18-21, 2006)

8. Assist IGEO in its technical program submissions for the IGC meeting in Oslo in 2008 (Continuing through IGEO contacts) 
9. Seek IUGS funding to match IGEO funds to support key educators from targeted developing countries to attend the next international GeoSciEd conference and receive training in relevant strategies to introduce and strengthen Earth science education and outreach in their countries (Continuing)

10. Examine funding possibilities and suitable models for operating training sessions on effective strategies for introducing Earth science education and outreach activities in targeted developing countries (Ongoing)

11. In the targeted countries, assist in the distribution of materials associated with teacher training sessions and make these materials available to other agencies and organisations for distribution as part of a wider teacher-training program.(Supporting ESEU to operate a program as part of IYPE)

12. Explore the translation of teaching materials into the languages of targeted countries, as appropriate. (Some materials in the US now translated into Spanish. Looking at this model for further work)

13. Explore the training of local educators to develop materials that are relevant and sensitive to the teaching, cultural, language and geological conditions of that country. (Supporting ESEU to operate a program as part of IYPE)

14. Encourage counties to participate in the Earth Science Olympiad. (Ongoing)

15. Provide advice and assistance for the International Year of Planet Earth when the program is formally confirmed. (Ongoing - two programs currently being supported by COGE) 
IUGS Commission on Geoscience Education, Training and

Technology Transfer (COGE)

Commission Work Plan and Budget Request 2007

\begin{tabular}{|l|l|l|}
\hline Item & Date Complete & Budget \\
\hline $\begin{array}{l}\text { Continue to develop website and } \\
\text { maintenance }\end{array}$ & end of Dec 07 & $\$ 2000$ \\
\hline $\begin{array}{l}\text { Support ESEU program by providing seed } \\
\text { funds for IYPE bid }\end{array}$ & March 07 & $\$ 2000$ \\
\hline Support for meeting/conf call costs & end of Dec 07 & $\$ 1,000$ \\
\hline Totals & & $\mathbf{\$ 5 , 0 0 0}$ \\
\hline
\end{tabular}

